\title{
Determinants of Banks' Technical Efficiency in Loans Allocation: Evidence from Côte d'Ivoire
}

\author{
Gahé Zimy Samuel Yannick ${ }^{1}$ \\ ${ }^{1}$ School of Economics and Management, Félix Houphouët-Boigny University, Abidjan, Côte d'Ivoire \\ Correspondence: Gahé Zimy Samuel Yannick, School of Economics and Management, Félix Houphouët-Boigny \\ University, Abidjan, 01 BP 5000 Abidjan 01, Côte d'Ivoire. Tel: 225-7827-9834. E-mail: sygahe @ hotmail.fr
}

Received: August 8, 2020

Accepted: September 16, $2020 \quad$ Online Published: December 31, 2020

doi:10.5539/ijef.v13n1p124

URL: https://doi.org/10.5539/ijef.v13n1p124

\begin{abstract}
The role of the financial sector is widely discussed in the economic literature. As part of this sector, banks in general and commercial banks specifically are at the front line. They are the first channels to finance the economy of a contry. Their funds come mainly from clients deposits. In an academic paper published some years ago, we assessed the efficiency of commercial banks operating in Côte d'Ivoire in converting deposits into loans. Even though the results were edifying, an important question remained: what are the factors that affect technical efficiency scores obtained? The present paper aims at answering this question. Based on a literature review, we identified several variables likely to impact the scores. Those variables are classified into two main groups. On the one hand, there are variables under the direct control of banks; on the other hand, there are variables that cannot be impacted by a given bank in a context of perfect competition. To conduct our study, we run a multiple regression model using Ordinary Least Squares. The dependent variable is the efficiency score. As per the potential explanatory variables, we take methodically some of those found within the literature in light of the context of the Ivorian bank market. The results reveal that bank specific factors are the most recurrent factors explaining variation in technical efficiency scores.
\end{abstract}

Keywords: technical efficiency, performance, ordinary least squares, bank market, Côte d'Ivoire

\section{Introduction}

\subsection{The Problem}

This article is an open window following a publication (Gahé et al., 2016) dealing with the assessment of the technical efficiency of commercial banks in Côte d'Ivoire in transforming deposits received from clients into credit to the economy. To conduct our analysis in this previous study, we use the Data Envelopment Analysis (DEA) method. The sample includes fourteen banks operating in Côte d'Ivoire.

Taking into account two main approaches of the DEA method, the results brings to light an average efficiency score of $48 \%$, from 2008 to 2010 , if we consider the hypothesis of constant return to scale. With respect to variable return to scale, this score would be $79 \%$. Also, it seems that private owned banks are relatively more efficient or less inefficient than state owned ones. All in all, the scores proved that generally speaking the commercial banks assessed were technically inefficient in converting resources into loans over the study period. This is mostly due to an incompatibility of production scale (scale inefficiency stands at $38 \%$ on average). The same statement may probably hold true if the remaining banks, which have not been included in the sample, were to be considered, since the sample accounts for $95 \%$ of the Ivorian banking industry in terms of market share. A primary insight into the determinants of efficiency variations reveals an incompatibility of production scale.

Now, we want to go further in the analysis. Indeed, the economic literature mentions several determinants of the performance of banks in terms of credit allocation. These determinants are summarized in different categories. Our approach therefore consists in considering methodically some of these factors in order to try to provide more explanation to the results of our previous study.

In short, our investigation aims at finding the factors that can explain the technical efficiency scores obtained from the assessment we did. From the results of the first work, we assume that variables inherent to banks decision area are the main impact factors. 


\subsection{The Previous Study}

Gahé et al. (2016) dedicates a study to the assessment of the banking industry of Côte d'Ivoire in terms of efficiency in converting clients' deposits into loans. It brings out that technical efficiency is the ability of a firm to maximize its outputs with a fixed quantity of inputs, or conversely, its ability to waste minimum quantity of inputs under the constraint of fixed quantities of outputs. It shows also that the measurement of technical efficiency is done in two main ways: parametric approach and non-parametric approach. The first one considers an efficiency function known in advance, while the second one assumes that efficiency is made up with the best units of the sample. The study adopts the latter approach through an implementation of the data envelopment analysis framework which throughout the literature reveals itself as a very useful and practical tool to evaluate banks' technical efficiency considering intermediation perspective.

The results bring to light an average efficiency score of 48\%, from 2008 to 2010, if we consider the hypothesis of constant return to scale. With respect to variable return to scale, the score is around $79 \%$. Also, it seems that private own banks are relatively more efficient or less inefficient that stated own ones. All in all the scores proved that generally speaking the commercial banks assessed were technically inefficient in converting resources into loans over the study period. This is mostly due to an incompatibility of production scale (scale inefficiency stands at 38\% on average). The same statement may probably hold true if the remaining banks, which have not been included in the sample, were to be considered, since the sample accounts for $95 \%$ of the industry in terms of market share.

\subsection{Determinants of Banks Performance}

In most of the literatures, there are two ways and sometimes three ways of classifying the determinants of bank performance. Al-Tamimi (2010) and Aburime (2005), for instance classified the determinant factors in to two: bank specific (internal) and macroeconomic (external) variables. Internal factors are individual bank characteristics which affect bank's performance. These factors are basically influenced by the internal decisions of management and board. External factors are sector wide or country wide factors which are beyond the control of the company and affect the profitability of banks. Other studies, Ongore (2011), attempted to integrate sector specific factors like bank ownership, bank size and concentration as a specific determinant of bank performance. This approach seems to segregate the external factor determinants in to sector specific and macroeconomic variables. However, some authors, (Chantapong, 2005; Olweny \& Shipho, 2011) focused on sector specific variables with total negligence of the macroeconomic variables like GDP and inflation. In general the two approaches seem similar in context and wide variation is not observed in classifying the determinants of bank performance and most of the researchers used both internal and external variables in their studies.

The next table summarizes the potential explanatory variables observed throughout the literature with their possible effects on efficiency scores.

Table 1. Summary list of potential variables

\begin{tabular}{|c|c|c|c|}
\hline VARIABLES & EXPECTED EFFECT & DEFINITION & VARIABLES CODING \\
\hline \multicolumn{4}{|c|}{ DEPENDENT VARIABLE } \\
\hline \multicolumn{2}{|l|}{ Total Technical Efficiency } & Efficiency Score under CRS & CRS \\
\hline \multicolumn{4}{|c|}{ INDEPENDENT VARIABLES } \\
\hline \multicolumn{4}{|c|}{ INTERNAL BANK/SPECIFIC FACTORS } \\
\hline \multirow{3}{*}{ Bank Size } & \multirow{3}{*}{-} & - Total Asset (Logarithm of total asset of bank) & AS \\
\hline & & $\begin{array}{l}\text { - Asset share of bank to market total share (market } \\
\text { share) }\end{array}$ & MS \\
\hline & & - Number of branches & $\mathrm{BR}$ \\
\hline \multirow{4}{*}{$\begin{array}{l}\text { Production Level: Loans } \\
\text { and Deposits }\end{array}$} & \multirow{4}{*}{$+/-$} & - Total volume of deposits & DP \\
\hline & & - Total volume of loans & LO \\
\hline & & - Sum of total deposits and total loans & SUM \\
\hline & & $\begin{array}{l}\text { - Ratio of bank credits to bank deposits } \\
\text { (Transformation Ratio) }\end{array}$ & $\mathrm{RT}$ \\
\hline \multirow{2}{*}{$\begin{array}{l}\text { Commercial } \\
\text { aggressiveness }\end{array}$} & \multirow{2}{*}{$+/-$} & - Credits growth rate & LG \\
\hline & & - Deposits growth rate & DG \\
\hline Credit risk & - & Loss & LOSS \\
\hline
\end{tabular}




\begin{tabular}{|c|c|c|c|}
\hline \multicolumn{4}{|l|}{ EXTERNAL FACTORS } \\
\hline \multirow{3}{*}{ Market Structure } & $+/-$ & $\begin{array}{l}\text { Ownership } \\
\text { - Proportion of foreign banks asset to total banks } \\
\text { assets }\end{array}$ & FBK \\
\hline & $+/-$ & $\begin{array}{l}>\quad \text { Concentration } \\
\text { - Concentration index }\end{array}$ & CONS \\
\hline & & - Total number of banks & $\mathrm{TB}$ \\
\hline Central bank Intervention & $+/-$ & Amount of operations with central bank & $\mathrm{CB}$ \\
\hline \multicolumn{4}{|c|}{ MACROECONOMIC FACTORS } \\
\hline Inflation & $+/-$ & Inflation rate & $\mathrm{CPI}$ \\
\hline \multirow[t]{2}{*}{ Economic development } & + & Real GDP growth rate & GR \\
\hline & + & GDP per capita & $\mathrm{PC}$ \\
\hline \multirow[t]{2}{*}{ Population } & - & Population density & $\mathrm{DE}$ \\
\hline & + & Population in largest city & PL \\
\hline
\end{tabular}

\section{Method}

\subsection{Data and Sample}

Data on banks come from the annual aggregated balance sheets published by the Bank of West African States. We also collect information from the database of the World Bank. Observations span from 1995 to 2015.

In practice, between 1995 up to 2002, some banks of our sample did not exist. We estimated the values of the variables for the sake of our analysis.

The original sample includes fourteen banks. However to ease the analysis, we will work with four banks extracted from the original population.

\subsection{Process}

Our analytical tool is Ordinary Least Squares technique. Using the software E-views we will run our model following different steps.

\section{Step 1: Selection of the Variables}

In practice, the variables presented earlier shall be filtered to keep those that meet the requirements for a multiple regression using a forward technique. Indeed, it is obvious that they cannot all be introduced in one model, at least as far as the years of observation are concerned.

First of all, we select the explanatory variable that has the highest correlation coefficient with the independent variable. The second step consists in adding one variable at first, then a second one while checking the significance of the model. When there are $\mathrm{k}$ variables, we add a variable that can improve the significance. The variables that do not pass the t-test shall be removed also.

\section{Step 2: Unit Root Testing}

The selected variables must be stationary in order to be incorporated into the model. To test this property we use the unit root test based on Augmented Dickey-Fuller (ADF) method.

\section{Step 3: Johansen Co-Integration Test}

One assumption for multiple regressions is that all the variables must be integrated of the same order otherwise they cannot lie in the same equation. The co-integration test helps analyzing the long run relationship of the model. Johansen Co-integration Test will serve at this stage.

\section{Step 4: Residual Diagnostic Tests}

Here we shall run the Residual Diagnostic Test, the Serial Correlation Test (LM-Test) and Heteroskedasticity. The first one is done using histogram-Normality test. The second one uses Lagrange Multiplier Testing (LM-Test). In case of serial correlation (probability higher than 5\%), the solution consists in including lag(s) of the dependent variable or that of the independent variables into the equation model. After we eliminate serial correlation, the model passes the same test again. As per the third test, it checks the presence of Heteroskedasticity.

Step 5: Stability Diagnostic

We adopt Ramsey and Recursive Estimates Tests. 


\subsection{The Model}

For a given bank, the final equation will be a regression of the total technical efficiency score by one or some of the potential explanatory variables. The model is as follows:

$$
\begin{gathered}
\text { Eff }_{\text {Score }}=f(\text { Explanatory Variables }) \\
\text { Eff }_{\text {Score }}=f\left(x_{1}, x_{2} \ldots x_{k}\right) \\
\left.C R S=\alpha_{0}+\alpha_{1} x_{1}+\alpha_{2} x_{2}+. .+\alpha_{i} x_{k}\right)
\end{gathered}
$$

$x_{1}, x_{2}, \ldots, x_{k}$ are the explanatory variables;

$\alpha_{1}, \alpha_{2}, \ldots, \alpha_{i}$ are the coefficients for each variable;

$\alpha_{0}$ is a constant;

$i=1,2, \ldots, k$;

$C R S$ is the total efficiency score.

\begin{tabular}{|c|c|c|c|}
\hline Model Number & Bank Name & Variables Short Name & Variable Full Name \\
\hline \multirow{5}{*}{1} & \multirow{5}{*}{ BFA } & - RT & - Transformation Ratio of Deposits into Loans \\
\hline & & $-\mathrm{LO}$ & - Loans \\
\hline & & - CONS & - Market Concentration \\
\hline & & - SUM & - Sum of Deposits and Loans \\
\hline & & $-\mathrm{AS}$ & - Total Asset \\
\hline \multirow{6}{*}{2} & \multirow{6}{*}{ BNI } & $-\mathrm{TB}$ & - Total Number of Bank in the market \\
\hline & & - LOSS & - Amount of Loss \\
\hline & & - FBK & - Ratio of Foreign Banks Asset among Total Banks Asset \\
\hline & & $-\mathrm{CPI}$ & -Consumption Price Index \\
\hline & & $-G R$ & - Real GDP Growth \\
\hline & & $-\mathrm{LO}$ & \\
\hline \multirow{2}{*}{3} & \multirow{2}{*}{ COFIPA } & - UP & - Urban Population \\
\hline & & -CPI; RT; LO; AS & \\
\hline \multirow{3}{*}{4} & \multirow{3}{*}{ BOA } & - DP & - Volume of Deposits \\
\hline & & - MS & - Bank Asset Share to Market Total Asset \\
\hline & & - AS; CONS; LO & \\
\hline
\end{tabular}

The process allowed us to get the models summarized in the next table.

Table 2. Regression models

\section{Results and Analysis}

\subsection{Model 1}

Considering R-squared (0.93) the model seems significant. Probability of F-statistic is also very low. That sounds good. Only ratio of transformation (RT), the total volume of loans (LO) and sum of total deposits and loans (SUM) pass the t-test because the probability associated to t-statistic is smaller than $5 \%$. This means it is not evident that the corresponding coefficients get a value of 0 .

The ratio of transformation of deposits into credits, as production level, has a positive but light impact on the efficiency of this bank in providing loans to its clients. In other words, as the amount of credits granted relatively to the volume of deposits available increases, this banks becomes more technically efficient in a certain extent.

As per the volume of loans, taking alone, if it increases, the bank technical efficiency is compromised due to the negative sign. The reason may be the cost related to loan allocation operations and also the risk involved for the present bank.

The total volume of deposits plus the total volume of loans has a positive impact on technical efficiency, the sign of the coefficient is positive.

It looks like the production level, represented by these variables, is part of the factors that could explain variation in the performance of this bank pertaining to credits allocation. The result is in line with what we expected as per the effect of production level. Throughout the literature we did not find a distinct and clear impact of production level. 
Based on our result, we can say that the impact of production level, as a factor under the control of bank, on the efficiency level is mixed. It can be either positive or negative depending on the production variable considered.

If we put the t-test aside, we can take a look at the other variables. Concentration (CONS), asset share of the five larger banks to total market share, has a positive impact on credit allocation's technical efficiency. The volume of asset affects our dependent variable negatively, i.e. the more this bank's asset is the less its level of efficiency is.

\subsection{Model 2}

R-squared and Probability of F-statistic look also interesting. The coefficient of loans is positive and its probability (0.0011) is less than 0.05 .

This result is almost the same as the previous one, for the first bank. Production level is a variable taken into account by the present bank neither. But this time, increasing the volume of loan is a good thing for the technical efficiency of this bank. An increase of $1 \%$ in the volume of loan boosts the efficiency by $2.45 \mathrm{E}-06$. It might be small but considering the huge amount of money banks channel, it is non-negligible.

Thus one can say that the effect of the production level on the efficiency score depends primarily on the credits policy of the bank itself. This shows that there are probably no constraining actions from the government to push banks to provide more credits.

In fact in Côte d'Ivoire, the banking sector is highly liberalized. The government is more concerned by attracting banks into the market than pushing them to provide more credits.

The amount of funds lost (LOSS) and inflation rate (CPI) decrease the performance. As per the asset share of foreign banks among total market share (FBK) and the real growth rate (GR), they have a positive impact on deposit transformation into loans, in this bank.

\subsection{Model 3}

For this model, volume of asset (AS) and inflation (CPI) produce a negative effect on technical efficiency score. These results are the same as in model one and model 2, respectively. Volume of loan (LO), ratio of transformation (RT) and urban population (UP) increase performance.

\subsection{Model 4}

Here when market share (MS) of this bank increases by $1 \%$ (ceteris paribus), its efficiency in allocating credits increases by $12.6 \%$. This amount is relatively important. The overall model presents an R-square good enough along with an interesting low probability of F-statistics.

Once again concentration (CONS) has a positive effect. The same result applies to loan (LO). As per volume of deposits (DP), it produces a negative impact. The coefficient associated to this variable is -0.30 . Thus when deposits increase by $1 \%$, ceteris paribus, technical efficiency score decreases by $30 \%$.

Table 3. Effects of the explanatory variables

\begin{tabular}{|c|c|c|c|c|c|}
\hline Model Number & Bank Name & Category of Bank & Variables Short Name & Type of variable & Coefficient sign \\
\hline \multirow{5}{*}{1} & \multirow{5}{*}{ BFA } & \multirow{5}{*}{ Public } & RT & Bank-Specific (BS) & + \\
\hline & & & LO & BS & - \\
\hline & & & CONS & Market factor (MF) & + \\
\hline & & & SUM & BS & + \\
\hline & & & AS & BS & - \\
\hline \multirow{5}{*}{2} & \multirow{5}{*}{$\mathrm{BNI}$} & \multirow{5}{*}{ Public } & LOSS & BS & - \\
\hline & & & FBK & MF & + \\
\hline & & & CPI & Macro & - \\
\hline & & & GR & Macro & + \\
\hline & & & LO & BS & + \\
\hline \multirow{5}{*}{3} & \multirow{5}{*}{ COFIPA } & \multirow{5}{*}{ Private } & UP & Macro & + \\
\hline & & & CPI & Macro & - \\
\hline & & & RT & BS & + \\
\hline & & & LO & BS & + \\
\hline & & & AS & BS & - \\
\hline \multirow{4}{*}{4} & \multirow{4}{*}{ BOA } & \multirow{4}{*}{ Private } & DP & BS & - \\
\hline & & & MS & BS & + \\
\hline & & & CONS & MF & + \\
\hline & & & LO & BS & + \\
\hline
\end{tabular}




\section{Conclusion}

Taking strictly into account the results of t-test, it appears that no matter the bank, none of the potential macroeconomic factors listed has a theoretical impact on the technical efficiency score. It is rather some factors directly related to banks that are significant. Those are the ratio of transformation of deposit into credits (RT) with a positive effect, the volume of loan available (LO) with a mixed impact depending on the bank, the sum of deposits and loans (SUM), and the market share of bank to the total market share (MS). In other words, the volume of production and the size of the bank in comparison to the other ones are non negligible factors to look at. However, considering the relatively high coefficient of determination along with the lower probability of F-statistics in each model, other variables can be taken into account in the models. Concentration (CONS) and asset share of foreign banks to market total share (FBK) have both positive impacts. They are market related variables. Volume of asset (AS), loss (LOSS) and deposits (DP) have all negative effects. They are bank-specific factors. Real GDP growth (GR), proportion of urban population in total population (UP) and inflation (CPI), as external factors produce respectively positive effects for the first two one, and negative action for the last one.

In summary, bank specific factors appear to be the most recurrent factors explaining variation in technical efficiency scores. Therefore, it seems that the financial authority of the country should take adequate actions to impact the behavior (bank specific factors) of bank in other to stimulate credit allocation. This concern could be the focus of another study.

\section{References}

Abu Bakar, N., \& Tahir, I. M. (2009). Applying Multiple Linear Regression and Neural Network to Predict Bank Performance. International Business Research, 2(4). https://doi.org/10.5539/ibr.v2n4p176

Aburime, T. U., \& Uche, C. U. (2006). Impact of Share Capitalization on Bank Profitability: Evidence from Nigeria. Annals of Finance, Forthcoming.

Aburime, T. U. (2005). Determinants of Bank Profitability: Company-Level Evidence from Nigeria. University of Nigeria, Enugu Campus, Nigeria.

Aburime, T. U. (2008). Determinants Bank Profitability: Macroeconomic Evidence from Nigeria. Deakin University, Working Paper, 1-10. https://doi.org/10.2139/ssrn.1231064

Agu, C. C. (1988). Nigeria Banking Structure and performance of the banking system's contribution to economic development. Onisha: African FEP publishers ltd.

Alexiou, C., \& Sofoklis, C. (2009). Determinants of bank profitability: Evidence from the Greek banking sector. Economic Annals, 182, 93-118. https://doi.org/10.2298/EKA0982093A

Al-Tamimi, H. A. H. (2010). Determinants of UAE Commercial Banks Performance. Retrieved from http://www.southwesternfinance.org/conf-2010/C8-1

Ameur, I., \& Mhiri, S. (2013). Explanatory Factors of Bank Performance; Evidence from Tunisia. International Journal of Economics, Finance and Management, 2(1), 143-152.

Athanasoglou, P., Brissimis, S., \& Delis, M. (2008). Bank-specific, industry-specific and macroeconomic determinants of bank profitability. Journal of International Financial Markets, Institutions and Money, 18(2), 121-136. https://doi.org/10.1016/j.intfin.2006.07.001

Berger, A. (1995). The profit-structure relationship in banking: Tests of market-power and efficient-structure hypotheses. Journal of Money, Credit and Banking, 27(2), 404-431. https://doi.org/10.2307/2077876

Berger, A., Hanweck, D., \& Humphrey, D. (1987). Competitive viability in banking: Scale, scope, and product mix economies. Journal of Monetary Economics, 20(3), 501-520. https://doi.org/10.1016/0304-3932(87)90039-0

Bourke, P. (1989). Concentration and Other Determinants of Bank Profitability in Europe, North America and Australia. Journal of Banking and Finance, 13, 65-79. https://doi.org/10.1016/0378-4266(89)90020-4

Chantapong, S. (2005). Comparative Study of Domestic and Foreign Bank Performance in Thailand: The Regression Analysis. The Office of Macroeconomic Policy and Analysis, Monetary Policy Group (MPG), The Central Bank of Thailand, 2005, Bangkhunprom. https://doi.org/10.1007/s10644-005-4523-5

Gahé, Z. S., Hongzhong, Z., \& Belinga, T. (2016). Technical Efficiency Assessment Using Data Envelopment Analysis: An Application to the Banking Sector of Côte D'Ivoire. Procedia - Social and Behavioral Sciences, 235, 198-207. https://doi.org/10.1016/j.sbspro.2016.11.015 
Kablan, S. (2007). Measuring bank efficiency in developing countries: The case of WAEMU (West African Economic and Monetary Union). African Economic Conference, November 2007.

Olweny, T., \& Shipho, T. M. (2011). Effects of Banking Sectoral Factors on the Profitability of Commercial Banks in Kenya. Economics and Finance Review, 1(5), 1-30.

Ongore, V. O. (2011). The relationship between ownership structure and firm performance: An empirical analysis of listed companies in Kenya. African Journal of Business Management, 5(6), 2120-2128.

Ongore, V. O., \& Kusa, G. B. (2013). Determinants of Financial Performance of Commercial Banks in Kenya. International Journal of Economics and Financial Issues, 3(1), 237-252.

\section{Copyrights}

Copyright for this article is retained by the author(s), with first publication rights granted to the journal.

This is an open-access article distributed under the terms and conditions of the Creative Commons Attribution license (http://creativecommons.org/licenses/by/4.0/). 